Battelle Nemorial Institute Pacific Northwest Laboratory Richland, Washington 99352 sponsored by the United States Government. Neither the United States nor the United States Atomic Energy Commission, nor any of their employees, nor any of their contractors, subcontractors, or their employees, makes any warranty, express or implied, or assumes any legal liability or responsibility for the accuracy, completeness or usefulness of any information, apparatus, product or process disclosed, or represents that its use would not infringe privately owned rights.

*This paper is based on work performed under United States Atomic Energy Commission Contract AT(45-1)-1830.

Presented to the Environmental Symposium sponsored by Oregon Technical Institute, Klamath Falls, Oregon, May 20 and 21, 1971. 


\section{DISCLAIMER}

This report was prepared as an account of work sponsored by an agency of the United States Government. Neither the United States Government nor any agency Thereof, nor any of their employees, makes any warranty, express or implied, or assumes any legal liability or responsibility for the accuracy, completeness, or usefulness of any information, apparatus, product, or process disclosed, or represents that its use would not infringe privately owned rights. Reference herein to any specific commercial product, process, or service by trade name, trademark, manufacturer, or otherwise does not necessarily constitute or imply its endorsement, recommendation, or favoring by the United States Government or any agency thereof. The views and opinions of authors expressed herein do not necessarily state or reflect those of the United States Government or any agency thereof. 


\section{DISCLAIMER}

Portions of this document may be illegible in electronic image products. Images are produced from the best available original document. 
BNWL-SA-3912

\title{
ENVIRONMENTAL PROBLEMS IN PRODUCTION OF ELECTRICITY FROM NUCLEAR PLANTS
}

\author{
J. K. Soldat \\ Battelle Memorial Institute \\ Pacific Northwest Laboratory \\ Richland, Washington 99352
}

\section{INTRODUCTION}

All of man's activities lead to some sort of an effect upon his environment. Generation of electricity is no exception - regardless of whether the power source is hydroelectric, fossil fuel or nuclear fuel. The principal environmental effects that have been associated with nuclear power facilities are potential radiological effects and the thermal effects of the heated condenser cooling water discharge. To a lesser degree, there are other environmental effects involving fish and wildlife, noise, sewage disposal, esthetics, recreation, etc. (I)

It should be noted that most all of these same problems exist with fossil fueled plants; although to different degrees. For example, because radium and associated radioactive materials are present in fossil fuels, the quantities of radioactive substances discharged to the atmosphere from a fossil fueled plant are not insignificant when compared with certain types of power reactors. (2)

The heat rejected to the cooling water per megawatt of electricity generated is somewhat higher for a nuclear power plant than for a fossil plant because the former have slightly lower thermal efficiencies than the latter ( 30 percent vs. 40 percent). As you are undoubtediy

\footnotetext{
*This paper is based on work performed under United States Atomic Energy Commission Contract AT(45-1)-1830.
} 
aware, several major studies are currently underway to explore beneficial uses for this rejected heat. Perhaps the next speaker will have more to say about the thermal effects of steam power plants on the environment. I would like to confine my remarks to evaluation of the radiological impact of nuclear facilities on the environment, a subject which has been my principal field of endeavor for the past two decades.

\section{SOURCES OF RADIOACTIVITY IN A NUCLEAR REACTOR '}

Radioactive materials are created in a nuclear reactor through several processes. (4) The primary source is, of course, the fissioning fuel. Since this fuel is in a chemical form designed to retain the fission products and is encapsulated besides, only a tiny fraction of these fission products ever escape to the coolout. A second source of fission products is fission of "tramp uranium" either picked up on the outside of the fuel elements during their manufacture or natural uranium present in the cooling water. Radioactive materials other than fission products are formed through neutron activation of certain impurities, chemicals, or corrosion products present within the reactor. Tritium is both a fission product and a product of nuclear reactions between the reactor's neutrons and chemicals deliberately added to the coolant for process control.

There are two major types of commercial nuclear power plants in operation today - the pressurized water reactor (PWR) and the boiling water reactor $(B W R)$. Both use demineralized water as the primary coolant which circulates through the reactor to remove the heat from the fissioning 
fuel for steam generation. In the PWR, the primary system is pressurized (2000psi) to prevent the formation of steam within the reactor. The steam is generated in a secondary coolant by means of an intermediate heat exchanger.

In a BWR; the pressure is lower (1000 psi) allowing direct formation of steam in the reactor. In both reactor types, the steam drives a conventional turbine, is condensed and then the liquid reused. A small amount of the coolant is bled off and treated for quality control and removal of some radioactivity. Radioactive gases are bled of $f$ the liquid stream and monitored and released to the atmosphere. In the PWR, the gases can easily be stored for 30-90. days before release to permit significant radioactive decay of the shorter-lived radionuclides. Because of the differences in design and operation, the two types of reactors have different quantities of various radionuclides in their aqueous and gaseous effluents. However, the amounts of radioactivity released to the environs from both types are insignificant when compared to the nationally and internationally recognized radiation protection standards. If fact, we can be quite contident that no member of the public in the U.S. has received a radiation exposure from the operation of a nuclear reactor that closely approximates the allowable annual limit. (3)

Before we look in more detail at the levels of radioactivity to be found in the vicinity of nuclear facilities, we should take a brief, look at the development and interpretation of radiation guides and standards. 
III. RADIATION PROTECTION GUIDES AND STANDARDS

From the beginning, the procedure for developing and establishing standards for protection against ionizing radiation has been the most comprehensive of any applied to environmental effects. The International Commission on Radiological Protection (ICRP) and the National Council on Radiation Protection and Measurements (NCRP) have been active in this field for the past 40 years. The Federal Radiation Council (FRC), whose functions were recently transferred to the new Environmental Protection Agency, was involved for over 10 years. The detailed quantitative and qualitative recommendations on radiation protection standards issued by these groups have served as the basis for the AEC's regulatory and health and safety programs. These standards groups have been strongly supported by research programs in laboratories in this country and throughout the world and by organizations such as the National Academy of Sciences, the Medical Research counc1l of the Unfted Klngdum and lhe Uniled Nations Scientific Committee on the Effects of Atomic Radiation.

The basic standards and guidance issued by these groups are reflected in the quantitative criteria in the regulations governing the nuclear power industry. This system of standards and regulations has proven to be very successful in limiting releases of radioactivity from nuclear t'acilities.

There is a great deal in the public press these days about the setting of limits both for maximum permissible exposure of people and for maximum permissible concentrations of radionuclides in effluents. from nuclear racilities. Recommendations on both types of limits were first made 
by the ICRP and NCRP. The recommended limits on radiation dose for both the public and the workers are intended to prevent appreciable injury, including both somatic and genetic effects, with the conservative assumption that there is no threshold below which radiation effects do not occur.

The limits are necessarily based on the concept of an "acceptable risk." In the genetic cases, the accumulated dose to the gonads up to the mean reproductive age of 30 years must not be so great that unacceptable damage to future generations results. In the case of somatic dose, the accumulated dose to a variety of tissues over the lifespan of the individual must not be so great that the risk of somatic damage becomes significant to that individual. In view of the conservative "no threshold" concept, the ICRP and NCRP are very clear in recommending that exposures always be kept as low as practical. At the very low dose rates recommended as the maximum for the public, one year has been selected as the appropriate interval of time over which to tally the radiation dose that accumulates.

As originally calculated by the ICRP and the NCRP, the Maximum Permissible Concentrations (MPC's) in air and water were derived from the maximum permissible doses that would accrue to the individuals during a lifetime ( 50 years) of consumption of such air and water.

With some slight modifications, these same limits have been translated into maximum permissible rates of intake of a radionuclide from all sources, by the Federal Radiation Council (FRC, now absorbed by the newly created Environmental Protection Agency). 


$$
\because \because \cdot-6-\quad \text { BNWL-SA-3912 }
$$

Partly because of the technical complexity of the behavior of a specific radionuclide once it enters the body and partly because of the need to simplify the standards for ease of administration, MPC's are now being used in ways that have little relation to the dose that might be received by people.

While streamlining the MPC's may be a necessary administrative expedient, such use has little place in any serious consideration of the actual annual radiation dose received by people. The current annual radiation limits are shown in the first figure.

Two sets of limits are quoted. One for controlling exposure to a "Maximum Individual" in the population and the other for the average exposure to the general public. The reduction by a factor of three for large population groups is an added safety factor for genetic considerations. The whole body limit for this group can be derived from the recommendation that the dose to the gonads be limited to a total of 5,000 mrem up to the mean reproductive age of 30 years for an average exposure of $170 \mathrm{mrem} / \mathrm{yr}$.

The principle limit promulgated by the AEC for nuclear t'acilities has been the one of $500 \mathrm{mrem} / \mathrm{yr}$ to the whole body of the "maximum individual." Because of the geographical location of power reactors in relation to the surrounding populations, it is not feasible to imagine a situation where the average exposure to a significant number of people in the vicinity could approach the limit of $170 \mathrm{mrem} / \mathrm{yr}$.

As a point of reference, it should be noted that the public is continuously exposed to natural background radiation at rates of $100-150$ 


$$
\therefore-7-\quad B \quad \text { BNWL-SA-3912 }
$$

mrem/yr and that for a significant biological effect to be noted, a person must receive a dose on the order of 100,000 mrem all at one time.

Figure 2 illustrates the relationship between the quantity of a given radionuclide contained in the human body and the radiation dose received. For example, a standard adult with a sustained body burden of 0.04 microcurie ( $\mathrm{uCi}$ ) of radioiodine ( $\mathrm{I}-13 \mathrm{l}$ ) would have 0.2 of this in his $20 \mathrm{~g}$ of $1500 \mathrm{mrem} / \mathrm{hr}$.

thyroid and would receive a thyroid dose/ This body burden would have to be maintained for a whole year by a continuous intake of I-13I to replace that which would be disappearing due to bodily elimination and radioactive decay. If the intake were discontinued, the dose in the succeeding 12 months while the remaining I-131 disappeared from the body would be only $45 \mathrm{mrem}$. Similar considerations apply to the other organs and nuclides illustrated in Figure 2.

The fate of a radionuclide in the body following a single ingestion is demonstrated in Figure 3. A person consuming 1 uCi, that is, 1000 nanocuries ( $\mathrm{nC} i$ ) of $\mathrm{zinc}-65(\mathrm{zn}-65)$ would rapidly excrete 90 percent of this. The other $100 \mathrm{nCi}$ would be absorbed through the small intestine and be deposited in the body. Barring a further intake of $\mathrm{Zn}-65$, this body burden of $100 \mathrm{nCi}$, would decrease as shown in Figure 3 to $1 / 2$ of this, or $50 \mathrm{nCi}$ after 194 days and again would decrease to $1 / 2$ of that or to $25 \mathrm{nCi}$ after another 194 days. This exponential decrease would continue until the $\mathrm{Zn}-65$ had all disappeared. The decrease results from a combination of biological elimination and radioactive decay.

A person continuously consuming $\mathrm{Zn}-65$ would accumulate a body burden which would not increase forever, but would eventually level off 
as shown in Figure 4. The equilibrium body Burden reached depends upon the rate of intake, the fraction which is absorbed into the body (10 percent in this example), and the rate of elimination. The maximum permissible rates of intake are derived from this long-term accumulated body burden, rather than the initial body burden acquired from a single ingestion.

Calculation of such intake rates and allowable concentrations in food are shown in Figure 5 for a few specific instances. Knowing the allowable annual whole-body dose of $500 \mathrm{mrem} / \mathrm{yr}$, one can calculate first the sustained body burden ( 6 uci) of $\mathrm{Zn}-65$ required to deliver this dose rate and second the rate of intake of $\mathrm{Zn}-65(80 \mathrm{uCi} / \mathrm{yr})$ required to maintain this body burden. If a diet survey revealed that this maximum individual consumed $60 \mathrm{lbs} /$ year of oysters, then oysters could contain up to $3 \times 10^{-3} \mathrm{uCi} / \mathrm{g}$ without resulting in the maximum consumer receiving a radiation dose greater than the standards specify.

The numbers in parentheses on Figure 5 are for the average person in the population whose radiation dose is limited to $1 / 3$ of that specified for the maximum individual. In our particular example, the average person is found to consume $1 / 3$ as 'many oysters (20 $1 \mathrm{bs} /$ year) so that the same maximum permissible $2 n-65$ concentration in oysters $\left(3 \times 10^{-3}\right.$ $\mathrm{uCi} / \mathrm{g})$ is derived for both persons.

For I-131, the maximum permissible concentration of $2 \times 10^{-6}$ $\mathrm{uCi} / \mathrm{ml}$ is for a maximum individual adult (with a $20 \mathrm{~g}$ thyroid) while the value of $1 \times 10^{-7} \mathrm{uCi} / \mathrm{ml}$ is for an average child (with a $2 \mathrm{~g}$ thyroid). 


$$
\therefore \ldots \cdot \because-9-\quad \therefore \quad \text { BNWL-SA-3912 }
$$

These calculated maximum permissible intakes apply when only one nuclide and one food is involved. Normally, however, a person can receive radiation exposure from several different radionuclides and from several different modes of intake. In addition, some radiation is also received from external sources. This complex network of exposure pathway is illustrated in Figure 6. Radionuclides released to the environment can be concentrated by plants or small organisms consumed by larger animals, which in turn are used for human food. The transfer of radionuclides through these food webs depends upon the particular nuclides involved. The ingestion of them by man depends upon his dietary habits. The external dose received depends upon man's residency and recreational habits in relation to the location of the contaminated environment. Examples of concentration factors of a few selected radionuclides in environmental media are given in the next four figures. Figure 7 illustrates the concentration factors for $\mathrm{Zn}-65$ in plankton, oysters, and fish from seawater. The pathway of exposure from $\mathrm{Zn}-65$ at Bradwell nuclear power station in the United Kingdom is shown in Figure 8 . The exposure pathway illustrated in Figure 9 is the one for Rhuthenium-106 (Ru-106) released to the Irish Sea at Windscale also in the U.K. The pathway here involves the unique dietary habit of consumption of laverbread made from seaweed.

Figure 10 describes the pathway of exposure which existed in the Columbia River downstream of the Hanford Project in Washington State when the plutonium production reactors were still: operating. This pathway involved phosphorous-32 (P-32) concentrated by Columbia River fish, 
subsequently eaten by local residents.

In contrast to commercial power reactors, the eight older plutonium producing reactors at the AEC's Hanford project utilized a oncethrough cooling system. Columbia River water was passed through the reactors, then into delay ponds, and finally back to the river. The coolant contained fission products and activation products from the same sources described above for power reactors. Since the cooling water in these older Hanford reactors was not confined to closed loops, the quantities of radionuclides released to the environment were significantly greater than those released from commercial power reactors. In fact, it has only been at $A E C$ sites like Hanford that sufficient radioactivity material has been released to permit accurate measurements of concentrations in environmental media.

The other exposure pathways associated with the discharge of reactor cooling water to the Columbia River are shown in Figure 11 . The external exposure pathways include swimming and boating in and on the river, occupying contaminated river shoreline while fishing, waterfowl hunting, or picnicking. The internal exposure pathways include consumption of river water, fish and waterfowl derived from the river, and consumption of crops, meat, eggs, and milk produced on land irrigated with water drawn from the Columbia River below the reactors.

In addition to the above pathways, there are those related to atmospheric releases principally from the reprocessing plants where the irradiated uranium from the reactors was chemically processed to recover plutonium and uranium. The operation of the chemical separations plant has 


$$
\because \because-11-\quad \therefore \quad \text { BNWL-SA-3912 }
$$

been curtailed subsequent to the reactor shut downs. The pathways of exposure from the atmospheric releases included deposition of radionuclides (principally I-13I) on the ground and transfer to vegetables, fruit, cereal, meat and milk produced on the contaminated ground. In the past, iodine-131, cesium-137, and strontium-90 from weapons test fallout have also been detected in these foods, in addition to low concentration of iodine131 of Hanford origin.

\section{ENVIRONMENTAL STUDIES AT HANFORD}

Because of the availability of measureable quantities of radioactivity, the Hanford environs has been the locus of several scientific studies, sponsored by the AEC and others, of the movement of radioactive materials through the biosphere and of the resultant radiation doses received by the local population. (These studies of course, are in addition to the extensive environmental sampling and analysis programs, and the studies of meteorology, hydrogology, reactor safety and management of radioactive wastes carried on at the large AEC sites.)

Initial environmental survey efforts at Hanford were aimed at detection and measurement of gross radioactivity. Later, as more sophisticated analytical methods were developed, specific radionuclides could be identified and traced through the environs in minute amounts. For example, the analytical method employed at Hanford in the 1950's for radioiodine in vegetation could detect $10^{-11} \mathrm{ppm}$. That is literally finding a needle in a haystack. A quantity of radioiodine the weight of an ordinary sewing. needle could be accurately measured after it had been uniformly 
dispersed in a giant hypotehtical haystack formed by harvesting all the alfalfa raised in seven years (at 2 cuttings/year) on all the arable land on our planet earth.

In early 1958, the staff of the Hanford environmental surveillance group compiled the first in a continuing series of comprehensive annual reports on the status of environmental radiation in the Hanford environs. (5)

This report, presented to the 2nd Geneva Conference on PUAE, demonstrated the feasibility of estimating the total radiation dose potentially received by local residents from external exposure and from consumption of food, air and water - provided certain diet, recreational, and residency factors were known. Each year's annual report estimated such radiation doses with increasing accuracy as a result of the environmental research carried on at Hanford. $(6,7)$

Some of the environmental studies carried out at Hanford are listed in Table I. Many of these studies involved the use of whole-body counters, instruments capable of directly measuring small amounts of certain radionuclides contained within the human body.

One such, whole-body is located in a room heavily shielded with iron to prevent natural background radiation such as cosmic rays from reaching the counter. The largescintillation detector used in this iron room is shown in Figure. 13. Another whole-body counter with more efficient, light weight shielding has been mounted in a mobile truck (Figure 14) for use at off-project areas, such as schools (Figure 15). The interior of this truck, shown in Figure 16, contains a moving cot 


$$
\therefore \because \quad \quad \therefore-13-\quad \text { BNWL-SA-3912 }
$$

which passes between shielded side walls and under a large scintillation detector (inside of large round shield). A typical measurement takes 10 minutes and the counting data is processed and stored on punched paper tape along with dietary information supplied by the person being counted.

Because of the interest in accurately defining the P-32 - fish pathway previously discussed (Figure 10), several studies of fishing habits and success have been made of the Columbia River immediately below the Hanford project. The most detailed was a year-long statistical study designed to determine the kinds and quantities of various species of fish being caught and the hours spent by fishermen on the shoreline harvesting these fish. For this study, a game-biologist actually visited various portions of the river shoreline and observed the catch. Some of the results of this survey are summarized in Tables II, III and IV. (8)

A follow-up household survey was made later in which fishermen were asked how many of each species of fish they had caught during the previous year. Comparison of the results from the two kinds of surveys indicated that fishermen on the average had remembered catching nearly four times as many fish as they were observed to catch. This result emphasizes the need for careful statistical design of population surveys to overcome the poor recall capability of people.

The results of such surveys, whole-body counting studies, and analysis of environmental samples can be used to (I) permit improved population dose estimates, (2) assist with problems associated with non-standard 


\section{$\therefore-14-\quad$ BNWL-SA-3912}

operating conditions, (3) guide the design of future environmental monitoring programs, (4) improve public acceptance of nuclear facilities, and (5) provide basic information concerning human uptake of radionuclides from the environment. (6)

The types of dose estimates that have been made for the Hanford environs are illustrated in Figures 17 and 18. As shown in these figures, the radiation doses to four principal organs - bone, GI tract, whole-body, and thyroid - attributable to Hanford were a small fraction of the radiation stándards.

As a result of the environmental studies conducted at AEC sites like Hanford and at numerous laboratories around the world, sufficient data has been accumulated to stimulate the development of comprehensive computer models for estimation of radiation doses. from the complex mixture of pathways and radionuclides expected from a future nuclear power complex. One such model under development at Battelle-Northwest is illustrated in Pigure 19. Not all of the necessary parameters are well known, but one of the purposes of the model is to define the areas where data is lacking.

This model is not yet complete. Examination of the preliminary re.. sults, however, indicate that even with the vast array nuclear power facilities predicted for the year 2000, the total radiation dose to the public will be a small fraction of the radiation protection standards. 
TABLE I .

$\therefore$ POPULATION SURVEYS AT HANFORD

(6)
Date

1960 1968

$1965-$ 1968

1969

$1967-$ 1968

19661969

1969

1969

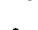

.

1970
Population Group and Survey

Plant employees measured with a Hanford wholebody Counter were asked to complete a diet survey form. A computer file of diet and whole-body counting data was prepared.(3)(4)

Elementary school children (5-12) in 17 local schools were surveyed with a whole-body counter and a 7-day diet record card. About $75 \%$ of the students voluntarily participated in the survey. (4)

Teen-aged students $(12-17)$ in a high school and a junior high school were surveyed with wholebody counter and oral diet and river recreation questions. About 50\% of the students responded.

\section{A statistically derived sampling program was} used to obtain information on Columbia River fishing. Stretches of the river were visited for 4-hour periods according to a schedule derived from random selection, and the fishermen interviewed. (5)

Whole-body counter and diet surveys were made of fishermen located at popular fjshing spots on 4 occasions.

A survey using the mobile whole-body counter and nral diet quections was conducted in a local rural area using Columbia River water for irrigation. Scheduling families to visit the whole-body counter became a community service project for $74-\mathrm{H}$ Clubs in the area.

Sludents in. Home bcon. classes in 2 local schools assisted in a survey of eating habits of family members. They estimated the size of servings taken by family members during the cours of 11 meals during a l-week survey period using handbooks containing pictures of 5 weighed serving sizes ifor 25 different varieties of foods.

A survey was conducted in 2 coastal communities locater near enough the mouth of the Columbla River that $\mathrm{Zn}-65$ from Hanford could be detected in local marine organisms. Both communities were centers for commercial seafood production.
Group

Size

About 7000

persons

About 5500

children

427

Teen-agers

2,132

Fishermen

interviewed

85

Fishermen

343

Fersons

250

Persons

462

Persons 
BNWL-SA-3912

TABLE . .II

COLUMBIA RIYER FISHING PRESSURE-LOCAL FISHERMEN ONLY

February 8,1966 to February $7,1967^{8}$

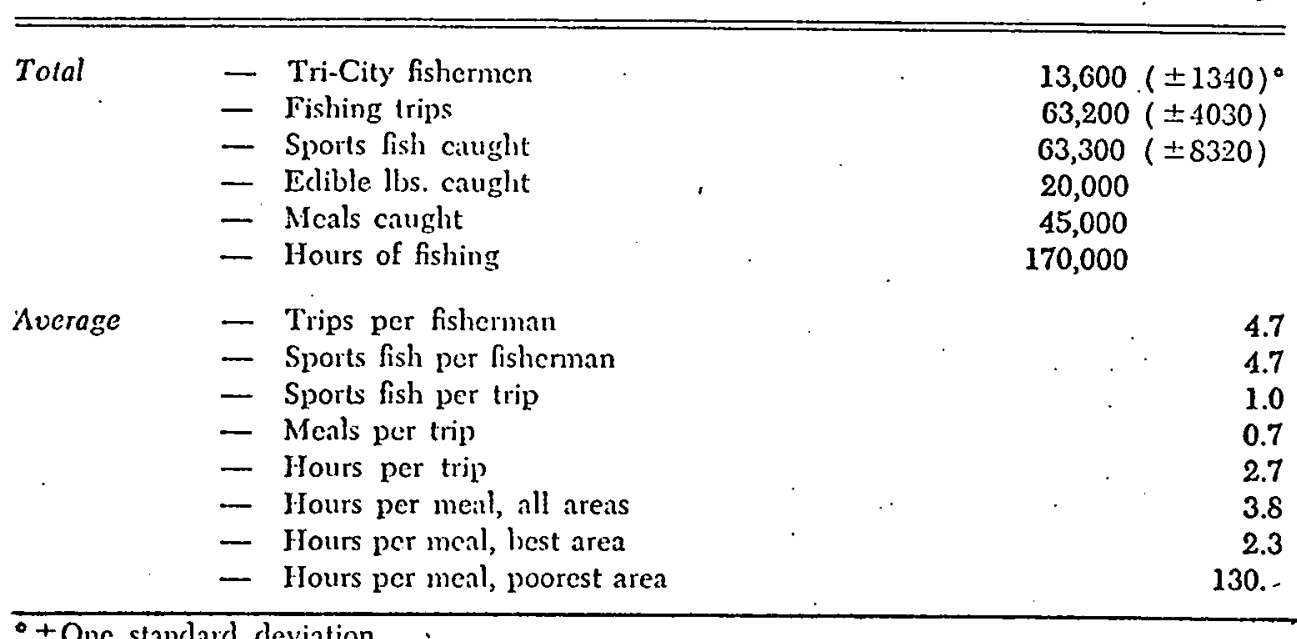

TAS̄LE -... MIT

ESTIMATED SPECIES DISTRIBUTION OF FISH CAUGHT BY TRY-CITY FISHERMEN,

February 8, 1966 to February 7,19678

\begin{tabular}{|c|c|c|c|c|c|}
\hline \multirow[b]{2}{*}{ Species } & \multirow[b]{2}{*}{ Number Caughto } & Per cent & \multicolumn{2}{|c|}{ Edible Weight (lb) } & \multirow{2}{*}{$\begin{array}{c}\text { Per cent } \\
\text { By W'eight }\end{array}$} \\
\hline & & By Number & Per Fish ${ }^{\circ}$ & Total $^{\circ}$ & \\
\hline Spiney Ray & $35,500( \pm 7,160)$ & 56 & $0.12 \cdots$ & $4,200( \pm 2,000)$ & 21 \\
\hline Catfish & $12,100( \pm 3,010)$ & 19 & 0.37 & $4,500( \pm 3,000)$ & 23 \\
\hline Bass & $11,900( \pm 2,890)$ & 19 & 0.30 & $3,600( \pm 2,000)$ & 18 \\
\hline Whitefish & $1,340( \pm 435)$ & 2 & 0.60 & $800( \pm 500)$ & 4 \\
\hline Tront & $1,180( \pm 490)$ & 2 & 0.30 & $350( \pm 200)$ & 2 \\
\hline Steclhead & $1,020( \pm 290)$ & 2 & 3.6 & $3,700( \pm 2,000)$ & 19 \\
\hline Sturgeon & $180( \pm 88)$ & 0.3 & 9.0 & $1,600( \pm 1,000)$ & 8 \\
\hline Salmon & $110( \pm 80)$ & 0.2 & 8.1 & $920( \pm 900)$ & 5 \\
\hline Sport fish & $63,300( \pm 8,320)$ & 100 & 0.32 & $20,000( \pm 10,000)$ & 100 \\
\hline Rough fish & $5,780( \pm 1,050)$ & - & - & - & - \\
\hline Total fish & $69,100( \pm 8,600)$ & - & - & - & - \\
\hline
\end{tabular}

- Numbers in parenthesis are one standard deviation.

- Estimated from measurements of fish collected for the biology rescarch and environmental monitoring programs over the past 20 yr at llanford. 
TABLE IV OCCUPATIONS OF TRI-CITY FISHERMAN 8 :

\begin{tabular}{lrc}
\hline \multicolumn{1}{c}{ Occupation } & \multicolumn{1}{c}{ Number $^{\circ}$} & \% of Total \\
\hline Student & $5,650( \pm 820)$ & 42 \\
Jianford employce & $1,7.30( \pm 360)$ & 13 \\
Housewife & $1,570( \pm 330)$ & 12 \\
Retired & $810( \pm 190)$ & 6 \\
Linemployed & $110( \pm 56)$ & 0.8 \\
Other & $3,420( \pm 510)$ & 25 \\
Unknown & $270(-)$ & 2 \\
Total & $13,560( \pm 1300)$ & 100 \\
\hline
\end{tabular}

- \pm One standard deviation. 


$$
\therefore \quad \therefore-15-\quad \therefore \quad \text { BNWL-SA-3912 }
$$

\section{REFERENCES}

1. L. R. Rodgers and C. L. Henderson, "AEC Implementation of the National Environmental Policy Act in its Licensing and Regulation of Nuclear Facilities," paper presented at the Third National Symposium in Radioecology, Oak Ridge, Tennessee, May 10-12, 1971 (proceedings in publication).

2. M. Eisenbud, "Standards of Radiation Protection and Their Implication for the Public's Health," pp. 73-87 in Nuclear Power and the Public (H. Foreman, ed.), proceedings of a symposium held at the University of Minnesota, October 10-11, 1969, University of Minnesota Press, Minneapolis, 1970.

3. R. F. Foster, "Nuclear Power Plants and the Environmental Crisis," Quest 8 (No. 4):11-16 (1970), Washington State University, College of Engineering, Pullman, Washington.

4. L. Spector, "Confrontation for the Atom," Machine Design, 42:20-28 (nn. 2.1) (September 3, 1970).

5. J. W. Healy, B. V. Andersen, H. V. Clukey, J. K. Soldat, "Radiation Exposure to People in the Environs of a Major Froduction Atomic Energy Plant," Proceedings 2nd Intermational Conference on Peaceful Uses of Atomic Energy, Geneva 18:309, UN Publishers, Pergamon Press, 1958.

6. J. F. Honstead, "Quantitative Evaluation of Environmental Factors Affecting Population Exposure Near Hanford," USAEC Report BNWL-SA3203, Pacific Northwest Laboratory, Richland, Washington. (1970).

7. C. B. Wilson, T, H. Essig, "Evaluation of Radiological Conditions in the Vicinity of Hanford for 1969," USAEC Reports BNWL-1505 and 1505-APP., Pacific Northwest Laboratory, Richland, Washington (1970). 


$$
\therefore-16-\quad \because \quad \text { BNWL-SA-3912 }
$$

8. J. K. Soldat, "A. Statistical Study of the Habits of Fishermen. Utilizing the Columbia River Below Hanford," pp. 302-308, in Environmental Surveillance in the Vicinity of Nuclear Facilities (W. C. Reinig, ed.), Charles Thomas, Springfield, Illinois (1970). 


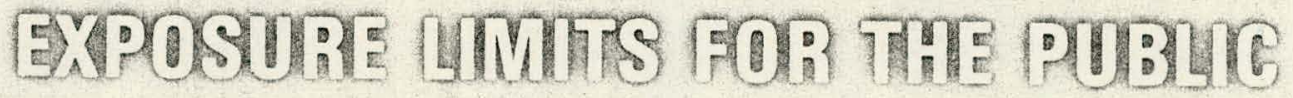
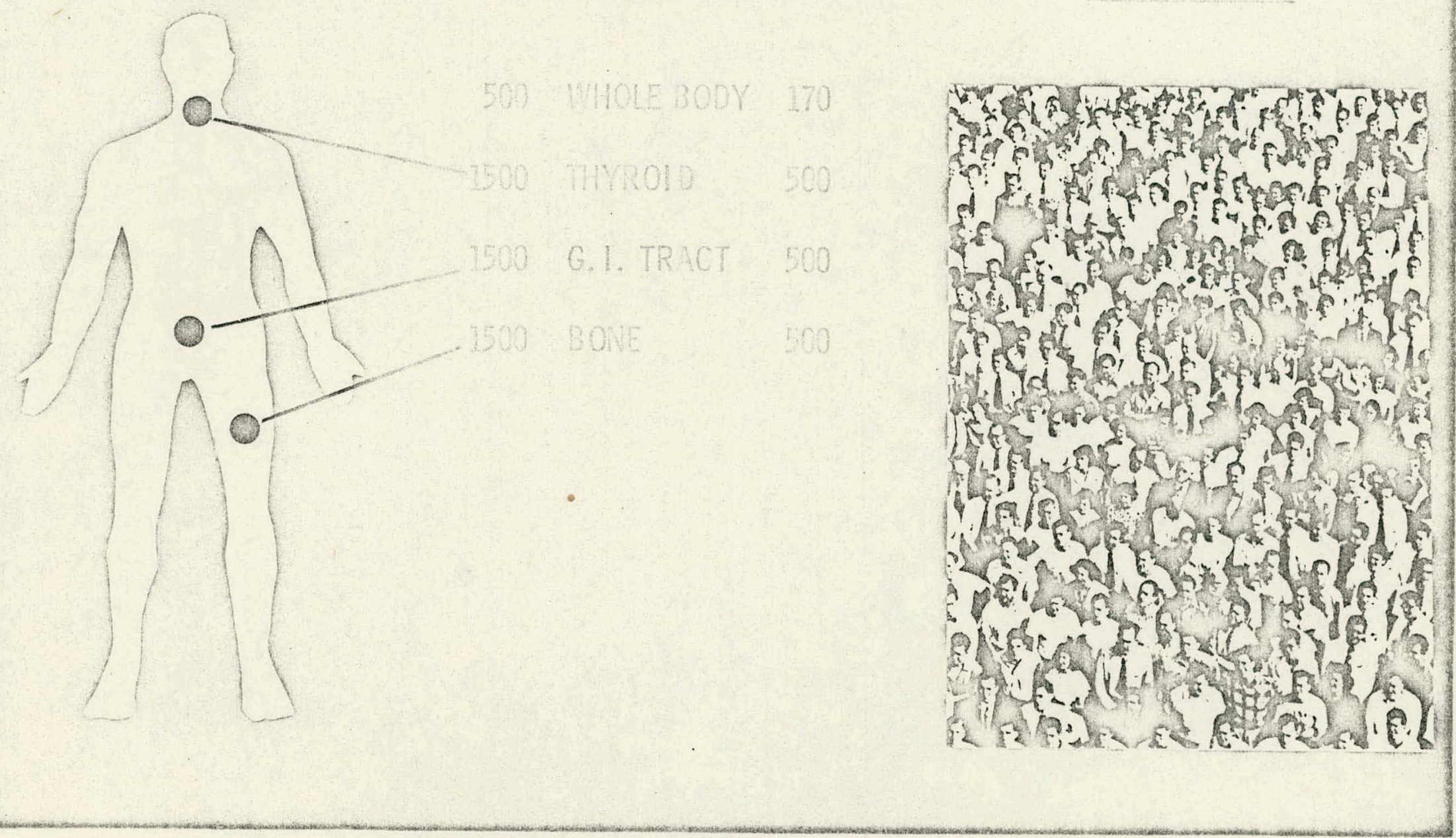


\section{BODY BURDEN YS DOSE}

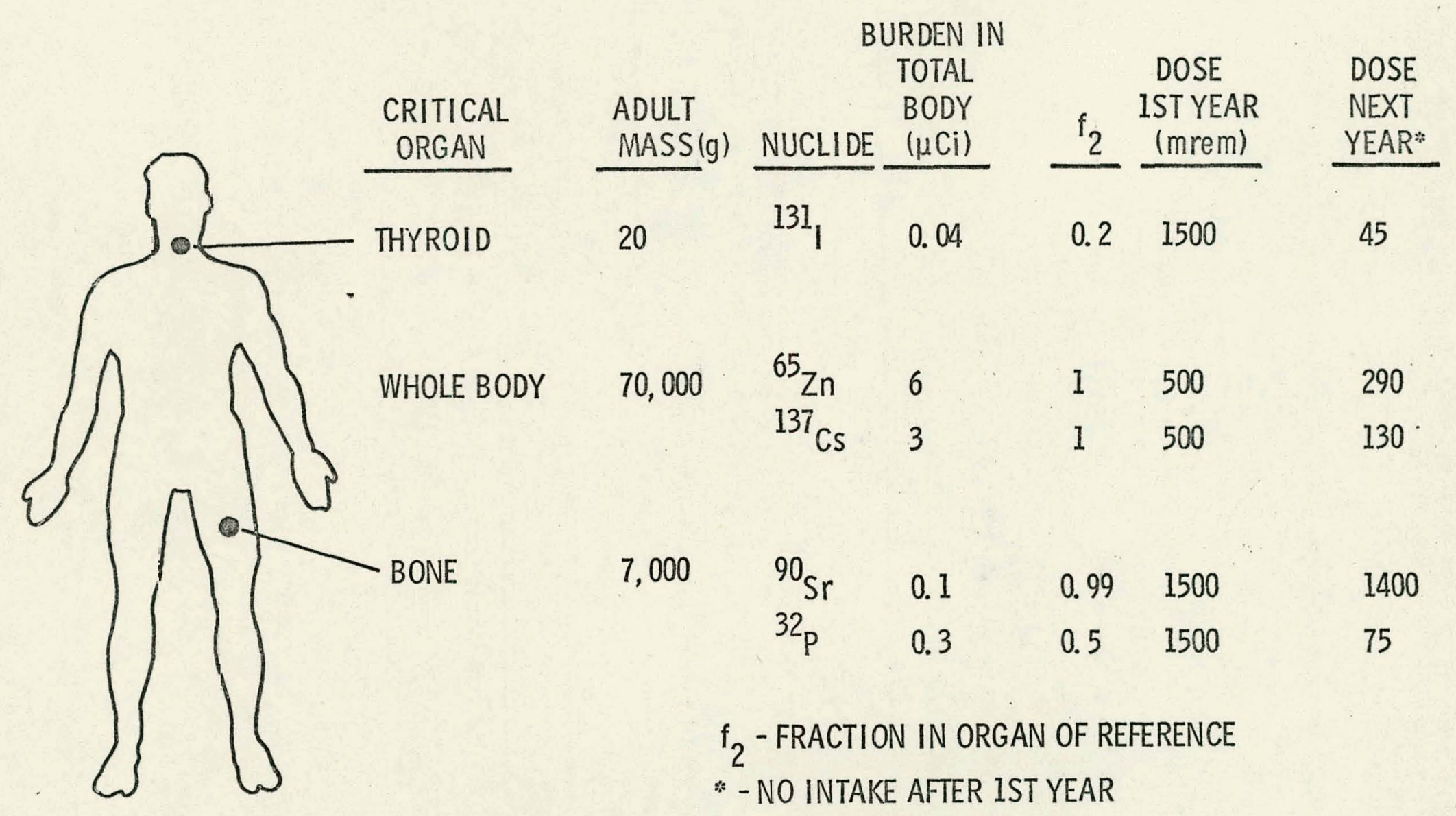




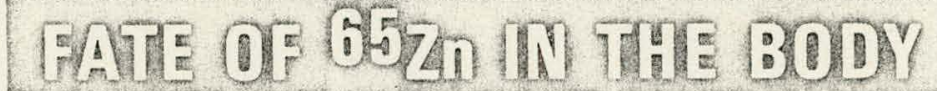

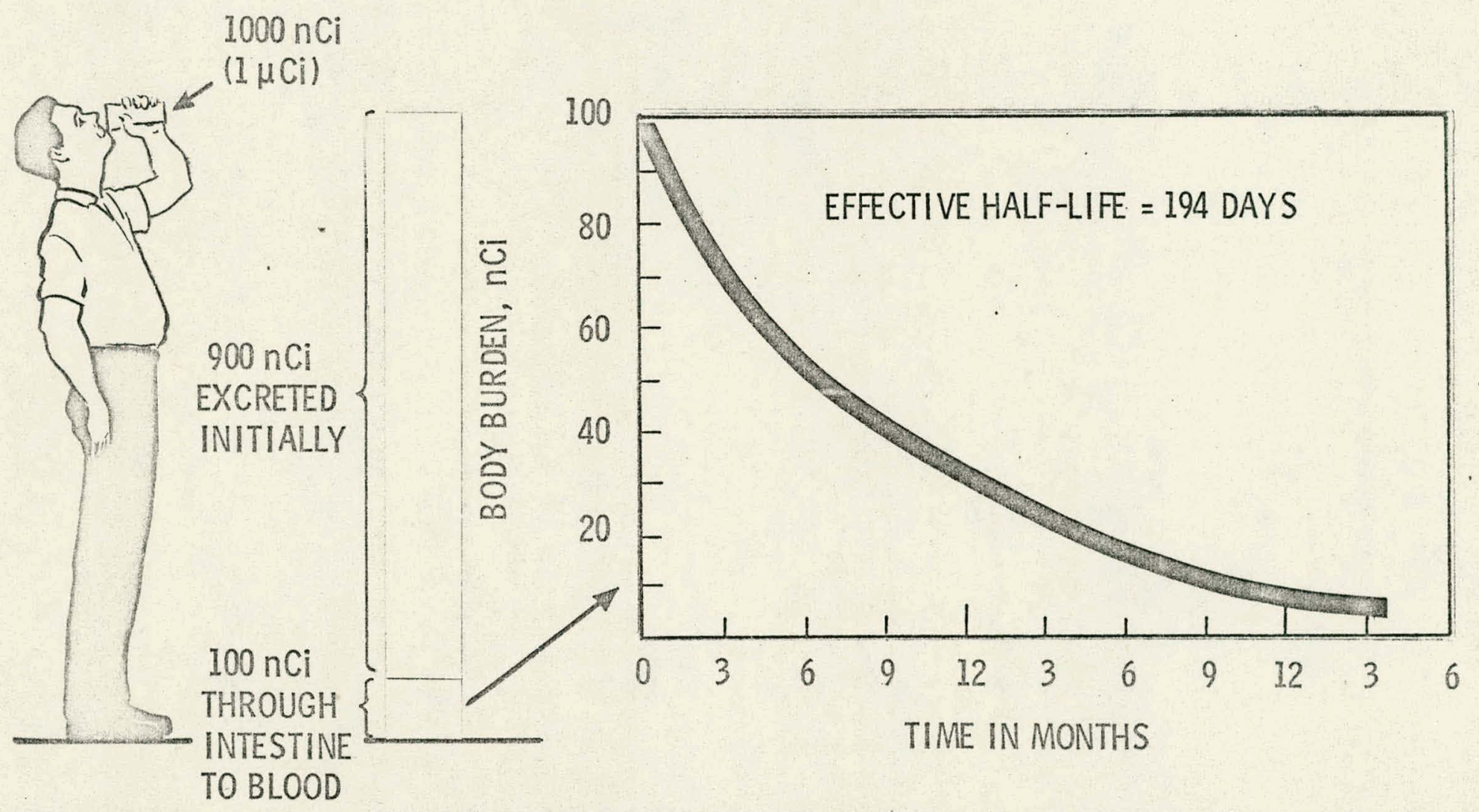




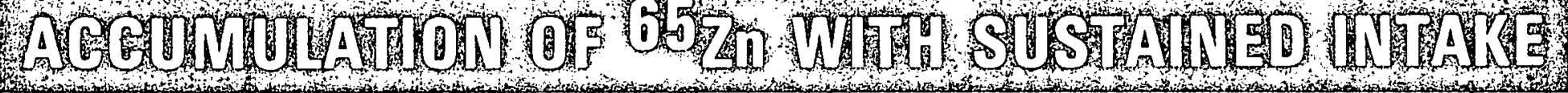

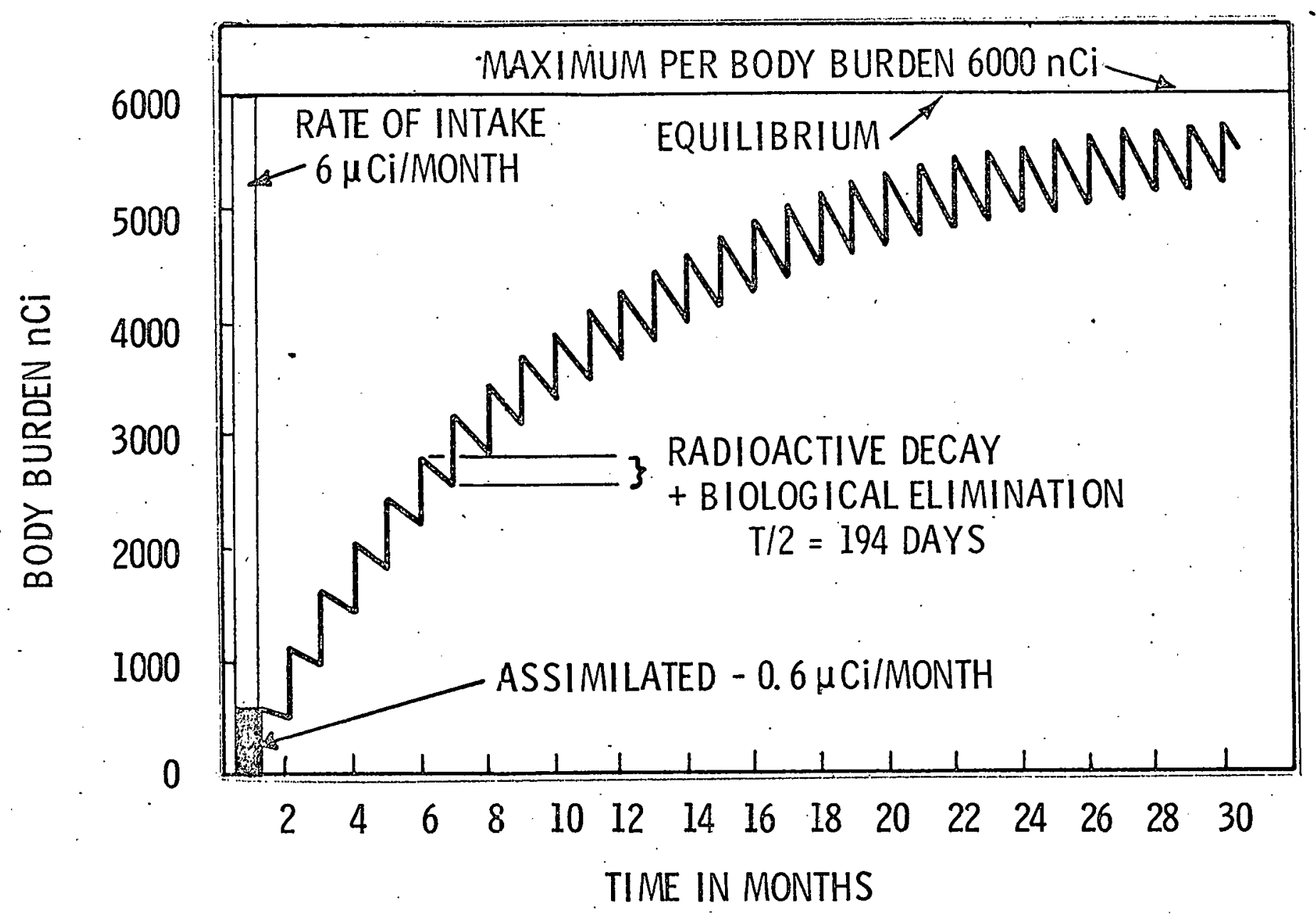




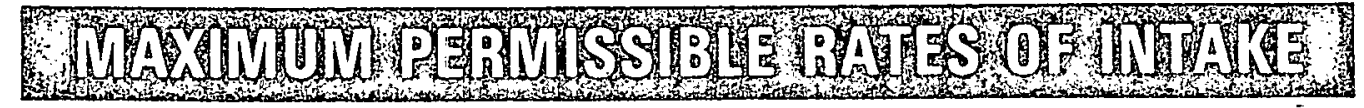

INDIVIDUALS AND (POPULATIONS)

\begin{tabular}{|c|c|c|c|c|}
\hline NUCLIDE & $\mu \mathrm{Ci} / \mathrm{DAY}$ & $\mu \mathrm{Ci} / Y E A R$ & FOOD \& CONSUMPTION & M.P.C. \\
\hline${ }^{3} \mathrm{H}$ & $\begin{array}{c}0.7 \\
(0.2)\end{array}$ & $\begin{array}{c}250 \\
(80)\end{array}$ & $\begin{array}{l}\text { WATER @ } 2.2 \text { I/DAY } \\
\text { (STANDARD MAN) }\end{array}$ & $\begin{array}{c}3 \times 10^{-3} \mu \mathrm{Ci} / \mathrm{ml} \\
\left(1 \times 10^{-3} \mu \mathrm{Ci} / \mathrm{ml}\right)\end{array}$ \\
\hline $32 \mathrm{p}$ & $\begin{array}{l}0.02 \\
(0.007)\end{array}$ & $\begin{array}{l}8 \\
(3)\end{array}$ & $\begin{array}{l}\text { FISH @ } 90 \text { LB/YEAR } \\
\text { (1 LB/YEAR) }\end{array}$ & $\begin{array}{c}2 \times 10^{-4} \mu \mathrm{Ci} / \mathrm{g} \\
\left(6 \times 10^{-3} \mu \mathrm{Ci} / \mathrm{g}\right)\end{array}$ \\
\hline${ }^{65} \mathrm{Zn}$ & $\begin{array}{l}0.2 \\
(0.07)\end{array}$ & $\begin{array}{l}80 \\
(27)\end{array}$ & $\begin{array}{l}\text { OY STERS } 60 \text { LB/YEAR } \\
\text { (20 LB/YEAR) }\end{array}$ & $\begin{array}{c}3 \times 10^{-3} \mu \mathrm{Ci} / g \\
\left(3 \times 10^{-3}, \mu \mathrm{Ci} / g\right)\end{array}$ \\
\hline $131_{I}$ & $\begin{array}{l}2 \times 10^{-3} \\
\left(8 \times 10^{-5}\right)^{*}\end{array}$ & $\begin{array}{l}0.8 \\
(0.03) *\end{array}$ & $\begin{array}{l}\text { MILK } 1 \mathrm{U} / \mathrm{DAY}{ }^{\prime} \\
(0.6 \mathrm{DAY})^{*}\end{array}$ & $\begin{array}{l}2 \times 10^{-6} \mu \mathrm{Ci} / \mathrm{ml} \\
\left(1 \times 10^{-7} \mu \mathrm{Ci} / \mathrm{ml}\right)\end{array}$ \\
\hline
\end{tabular}

"INFANT WITH $2 \mathrm{~g}$ THYROID 
DOSTE CALCHSATONS

PEOPE

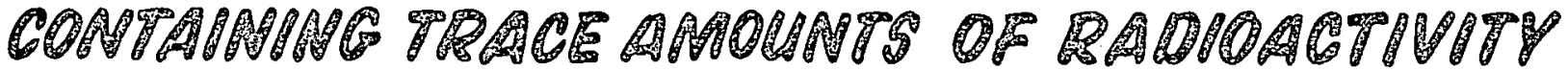

"ANTERNAL DOSE"

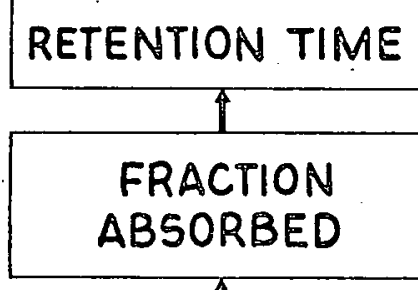

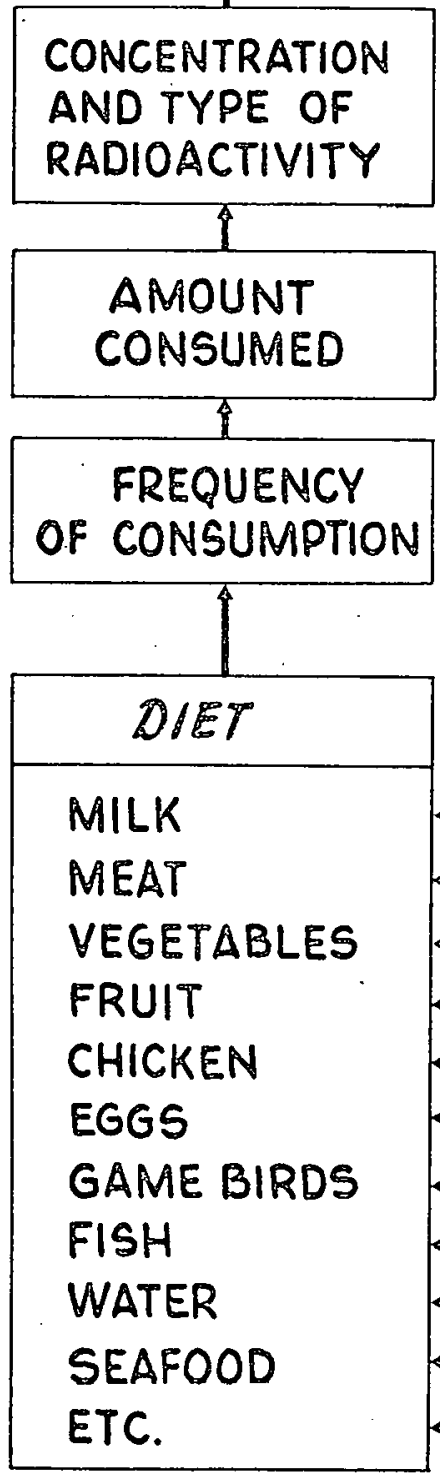

"EXTERNAL DOSE"

\begin{tabular}{|l|}
\hline $\begin{array}{l}\text { AFFECTED } \\
\text { ORGANS }\end{array}$ \\
\hline TOTAL BODY \\
BONE \\
G.I.TRACT \\
THYROID \\
LUNG \\
\hline
\end{tabular}

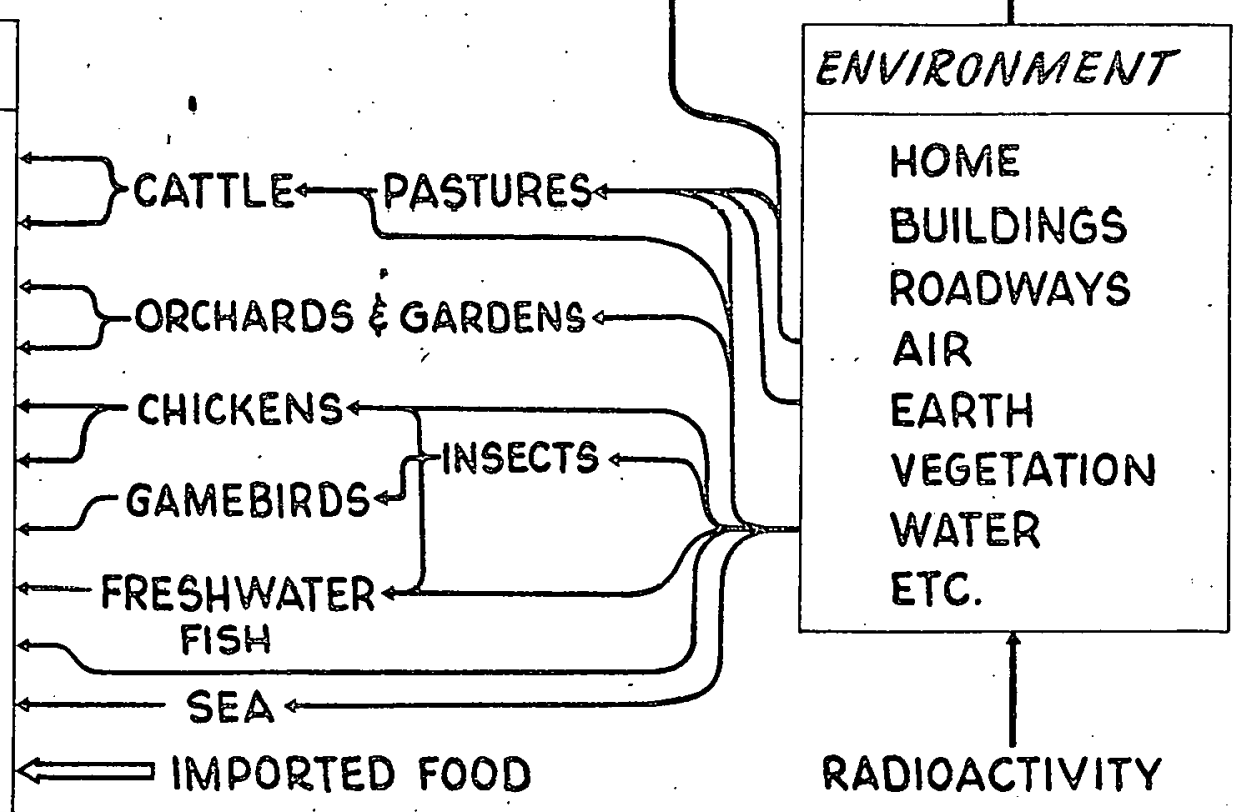




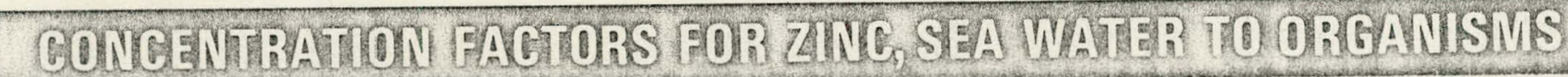

Zn CONCENTRATION IN SEA WATER
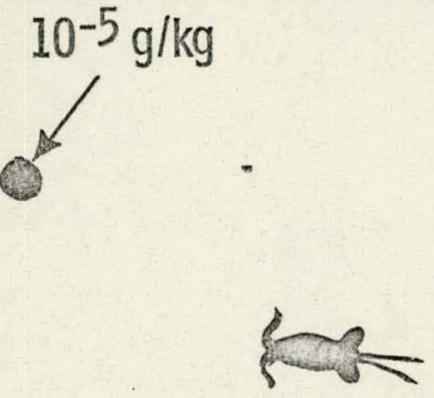

PLANKTON $10^{-1} \mathrm{~g} \mathrm{Zn} / \mathrm{kg}$

C. $F_{0}=10,000$

OYSTER FLESH

$10^{-1} \mathrm{~g} \mathrm{Zn} / \mathrm{kg}$

C. F. $=10,000$
-

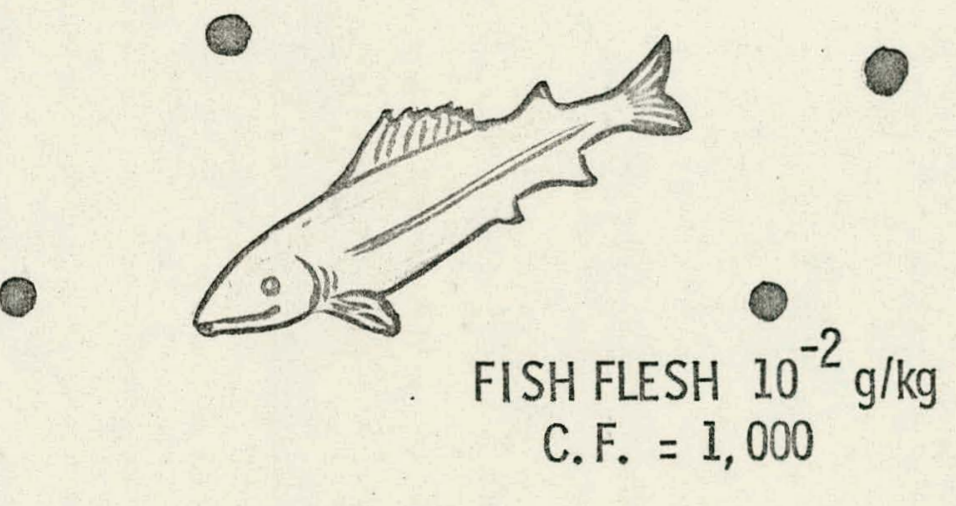

-

2

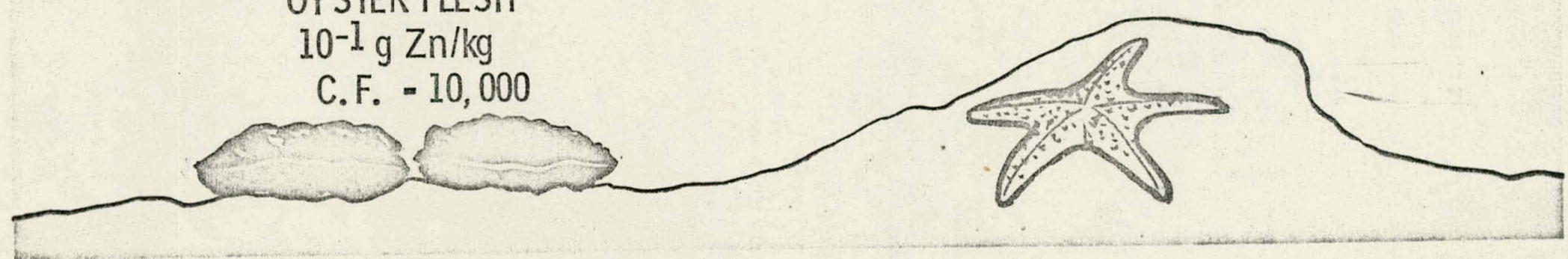




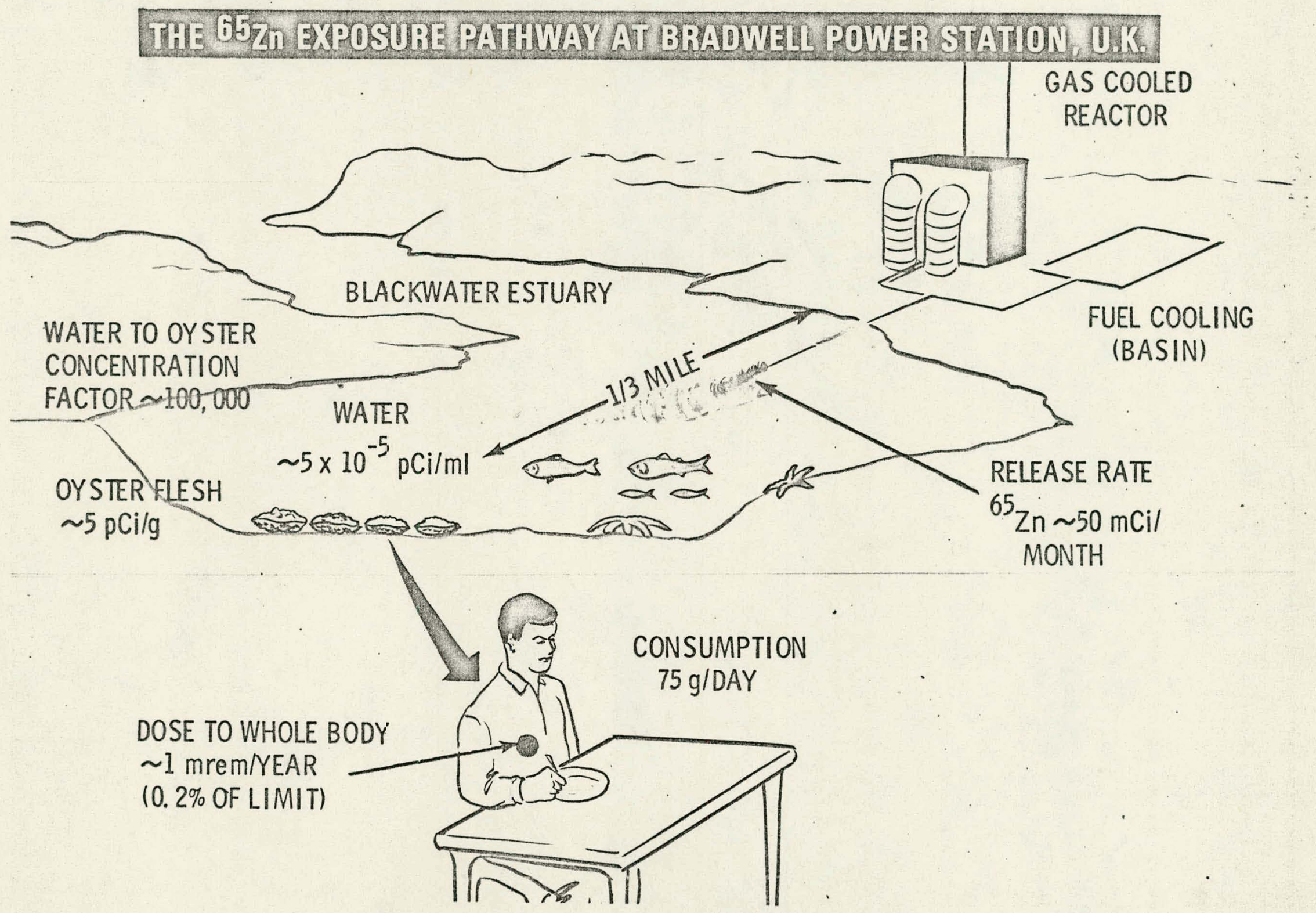




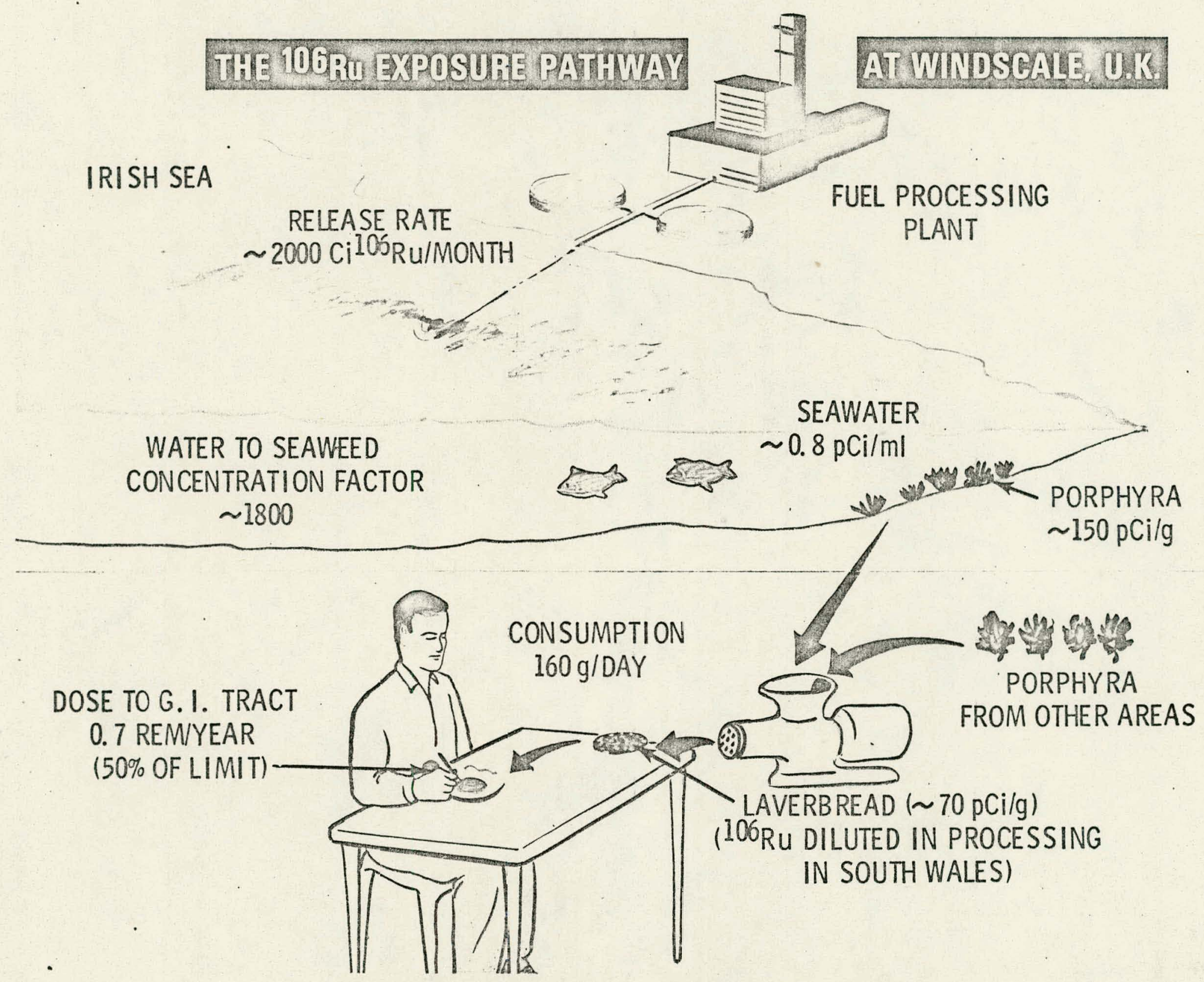




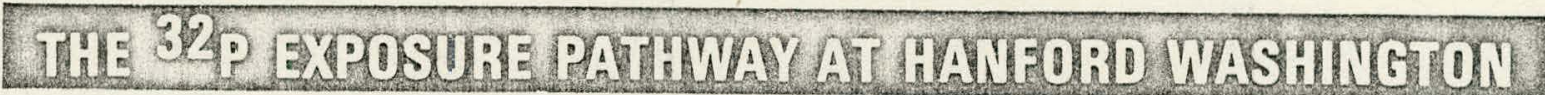
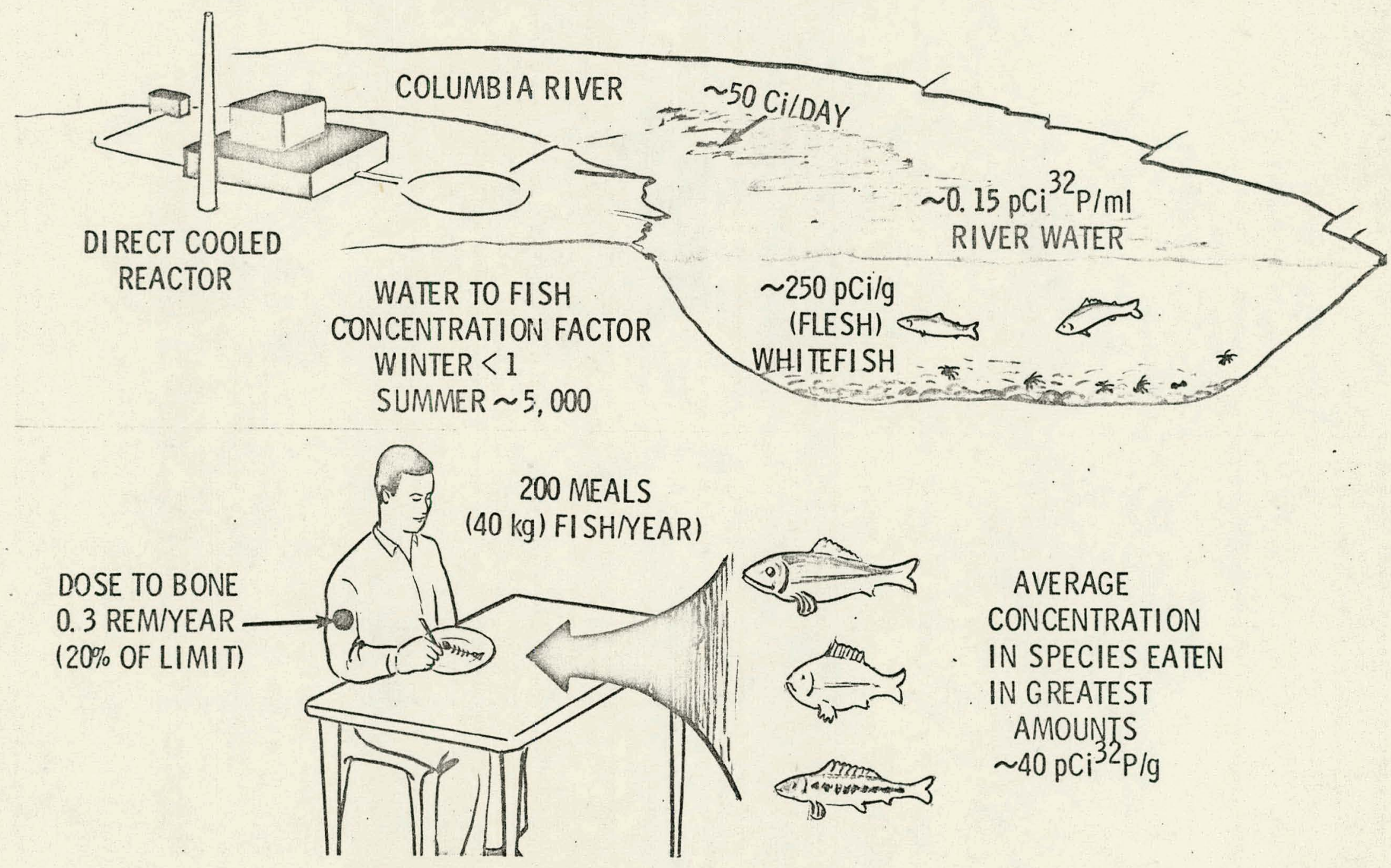


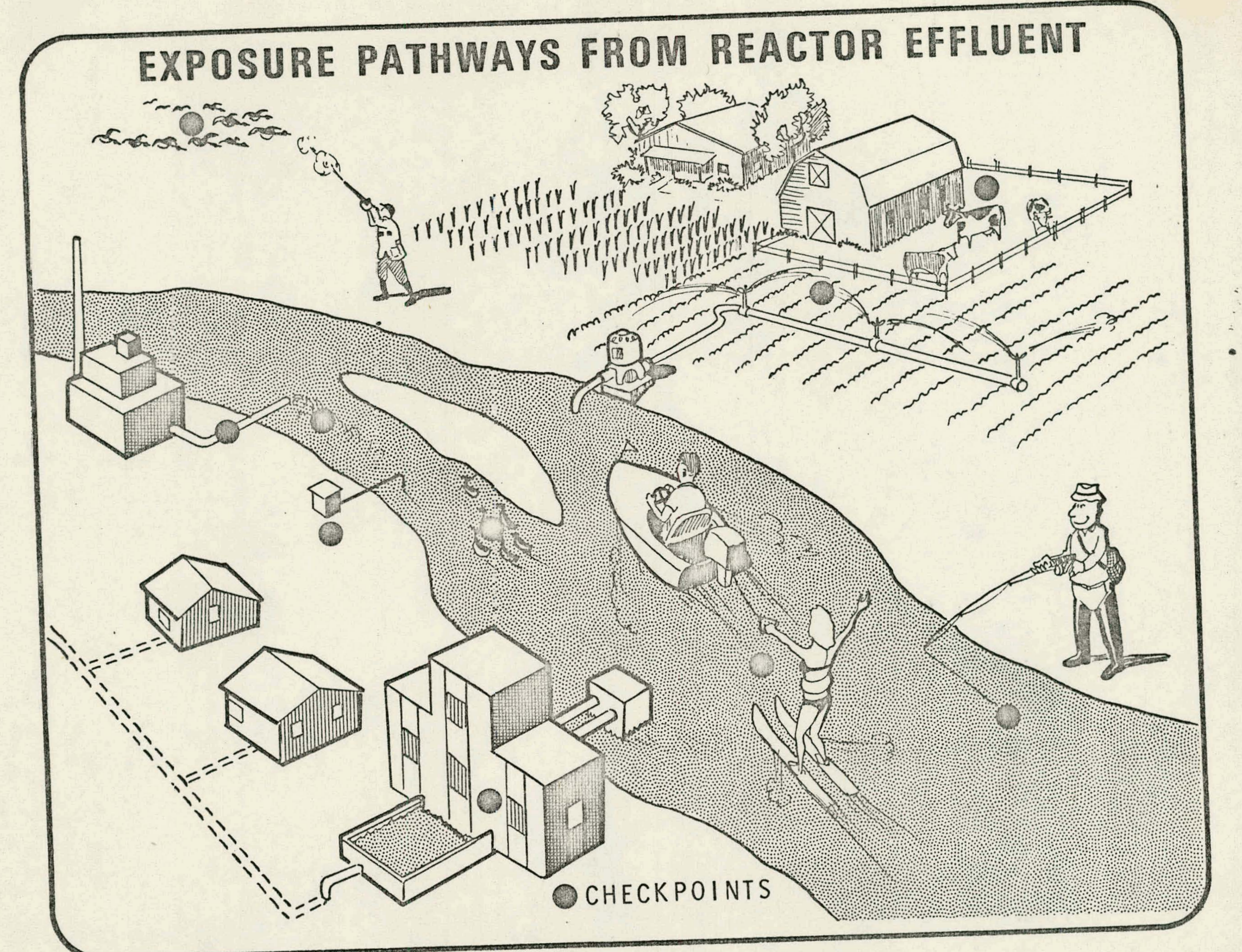




\section{EXPOSURE PATHWAYS FROM THE ATMOSPHERE}

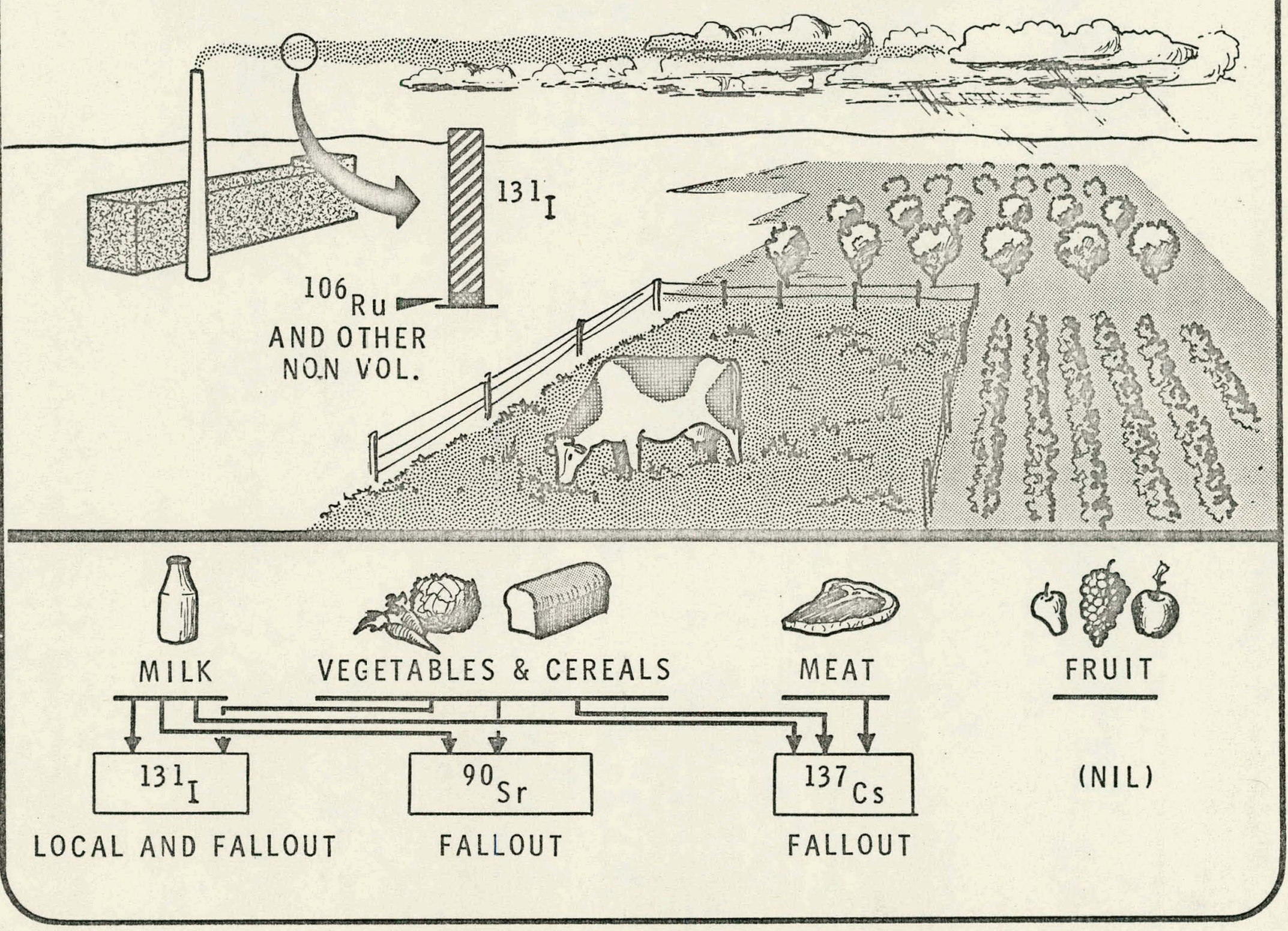




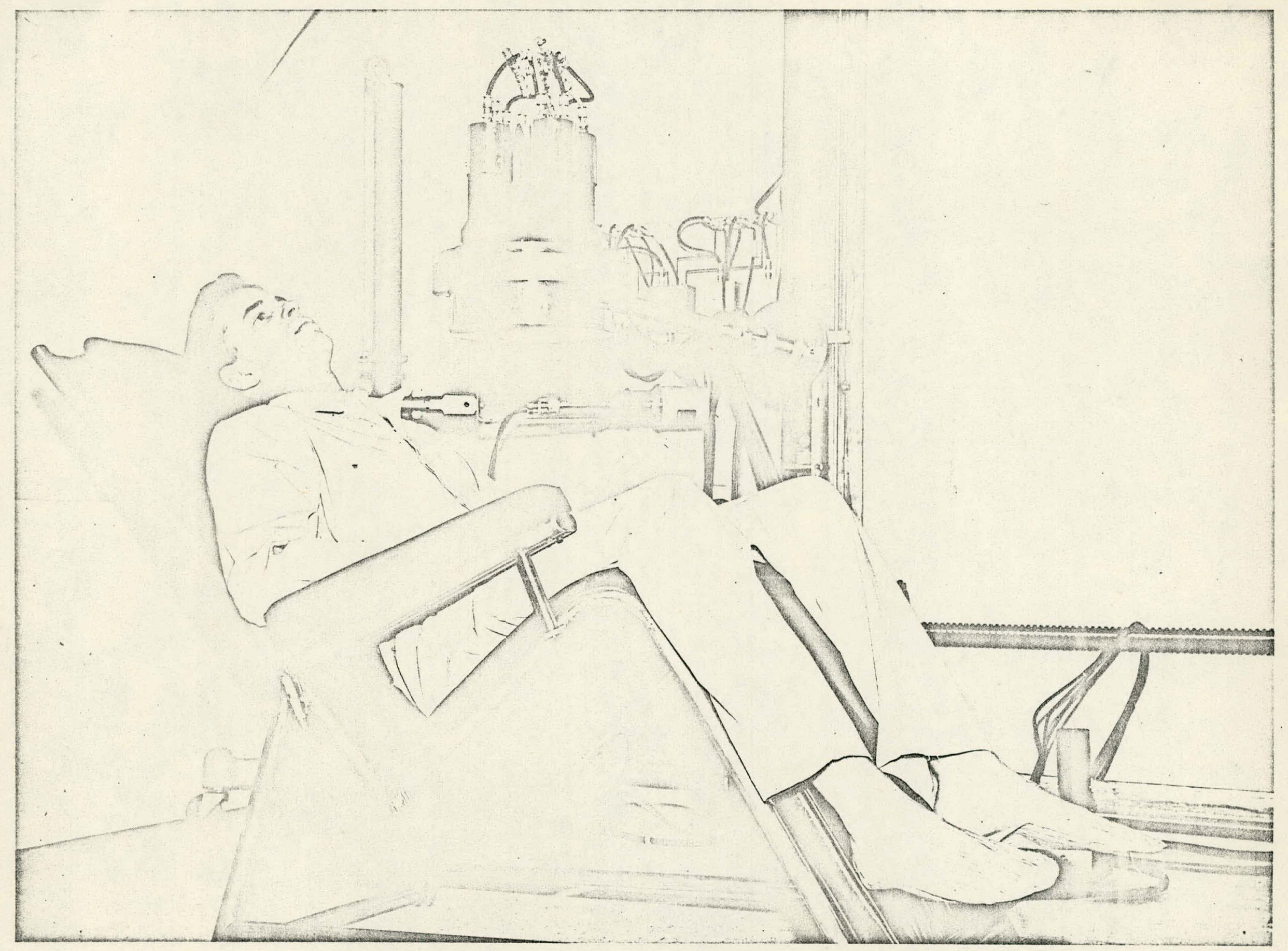

FIGURE 13 STATIONARY WHOLE-BODY COUNTER, HANFORD 


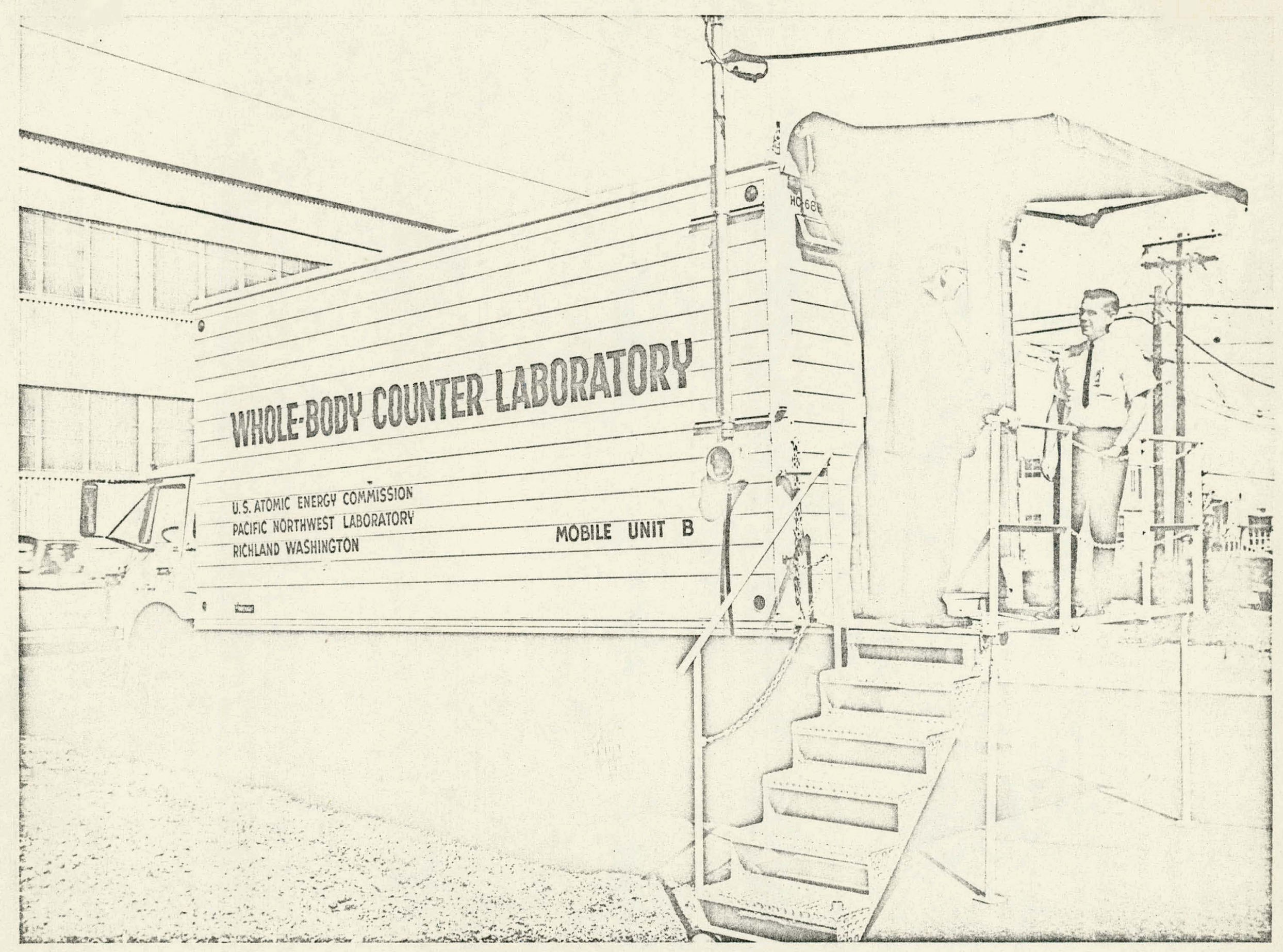




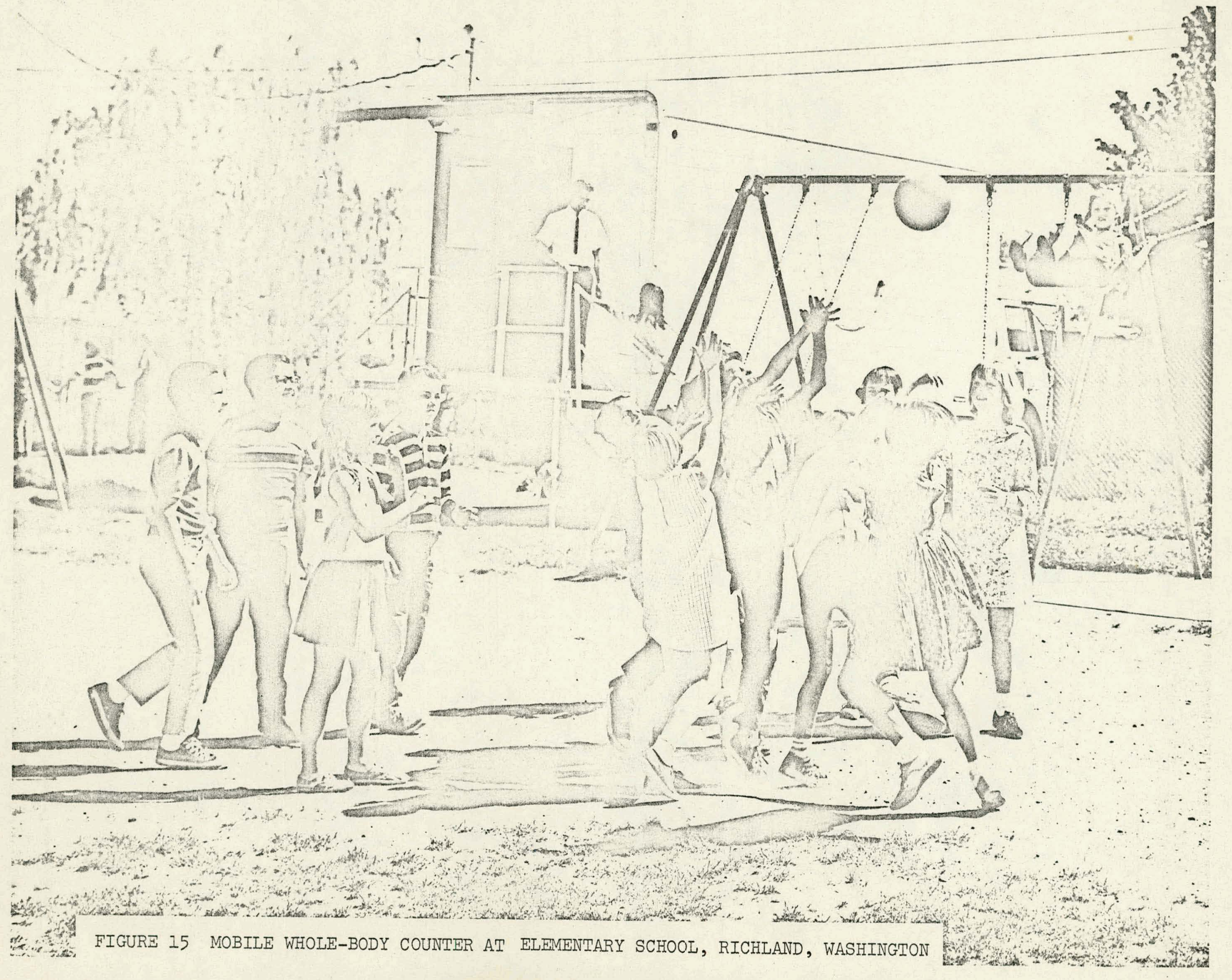




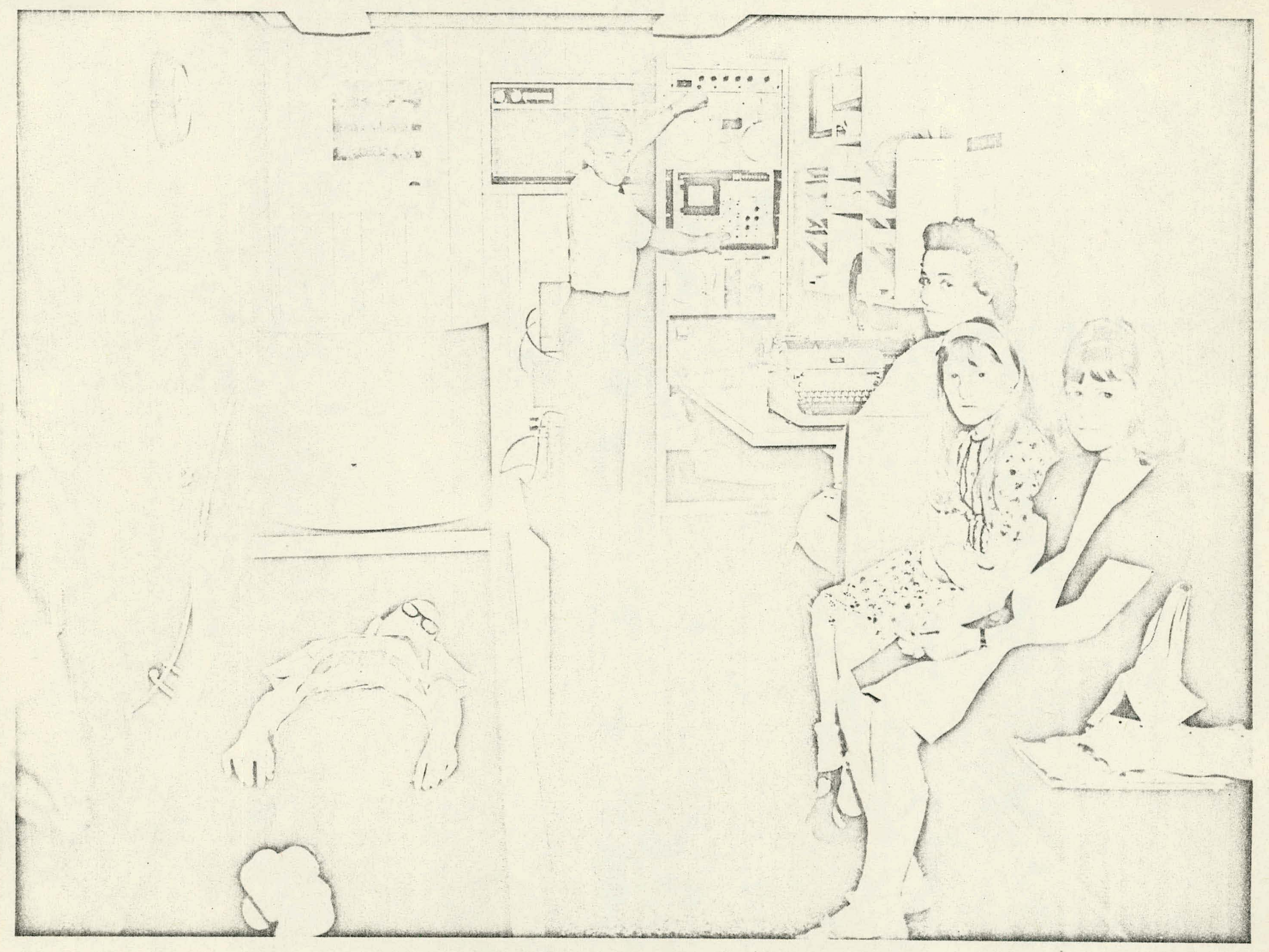

FIGURE 16 INTERIOR OF MOBILE WHOLE-BODY COUNTER 


\section{ESTIMATED DOSES TO THE MAXIMUM INDIVIDUAL - 1969}

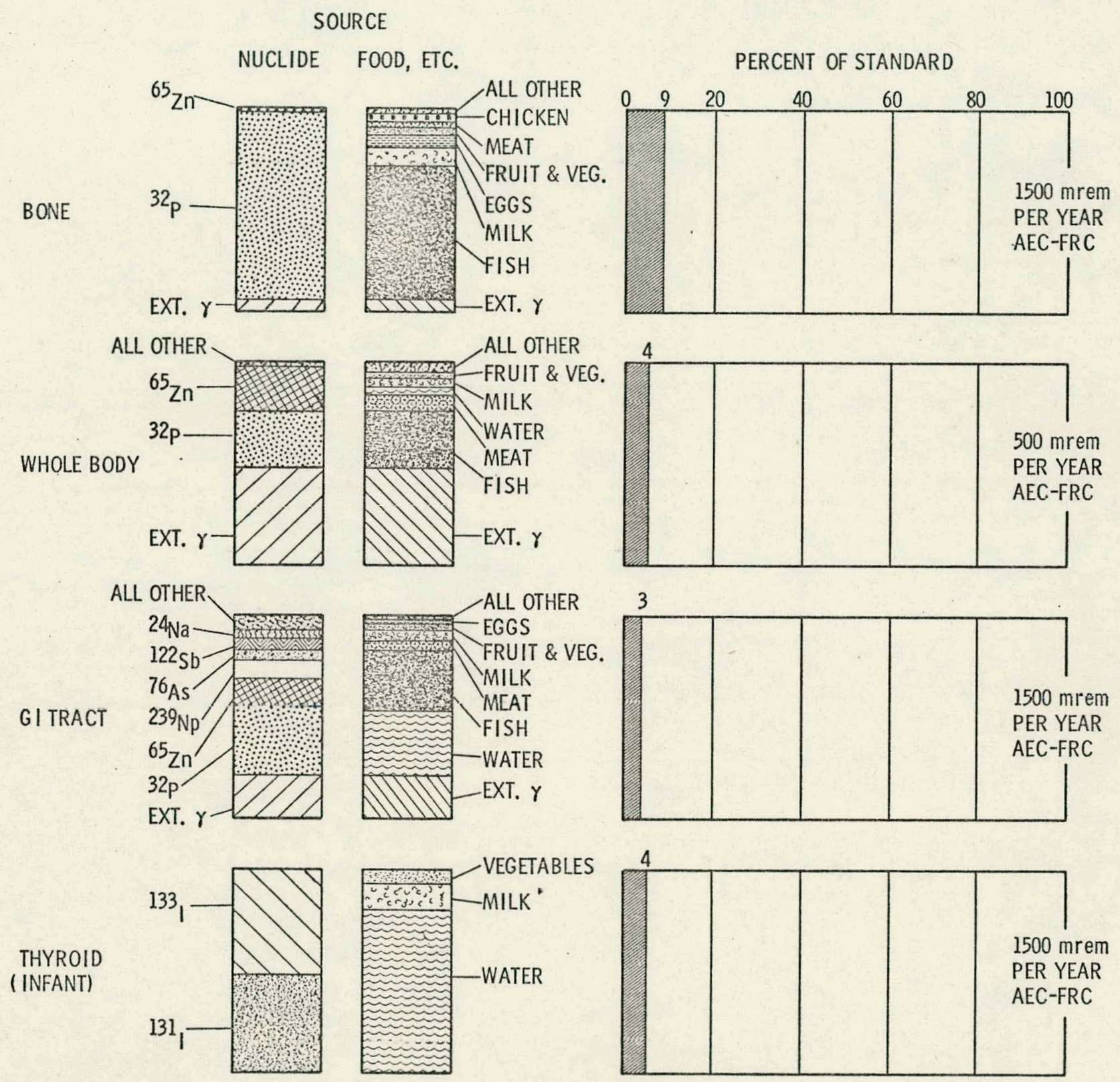




\section{ESTIMATED DOSES TO THE AVERAGE RICHLAND RESIDENT-1969 SOURCE}
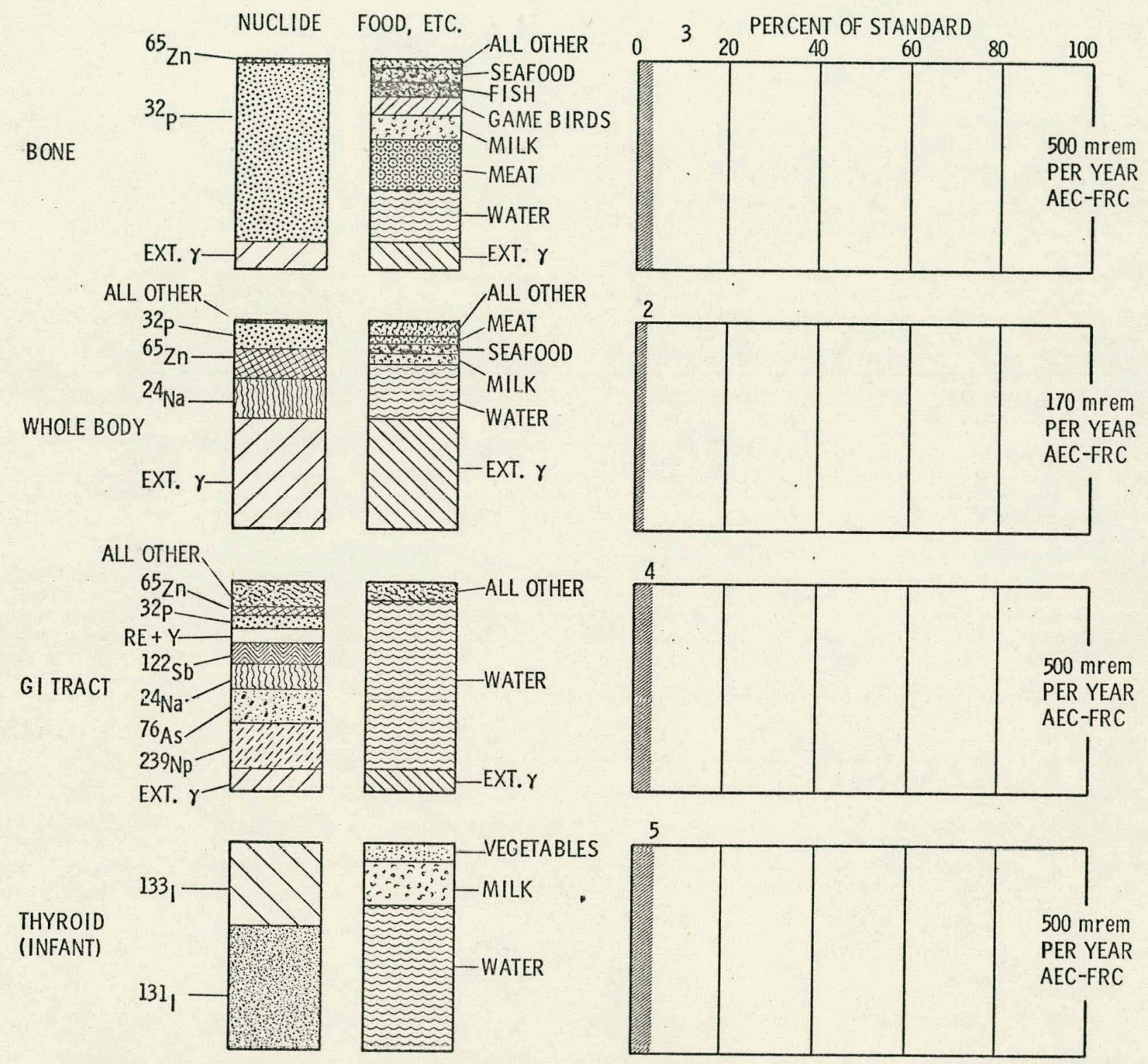


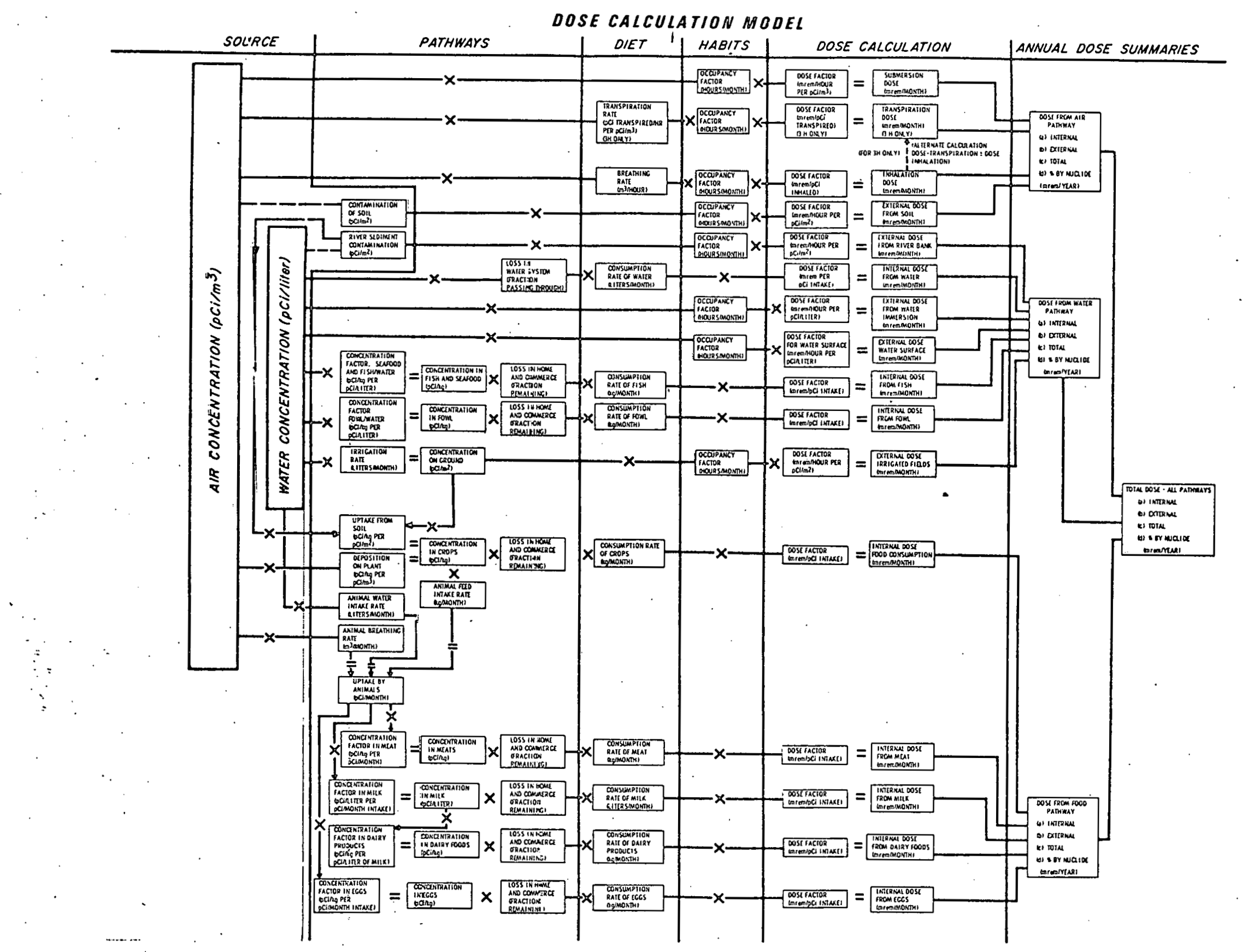

